\title{
Wybrane ośrodki turystyczne w Sudetach jako lokalne rynki pracy
}

\author{
Autor: Robert Szmytkie
}

\begin{abstract}
Abstrakt
Głównym celem artykułu jest ocena wpływu turystyki na rynek pracy w małych miastach, będących ośrodkami turystycznymi. Analizę przeprowadzono na przykładzie 8 małych miast województwa dolnośląskiego (Duszniki-Zdrój, Karpacz, Kudowa-Zdrój, Lądek-Zdrój, Polanica-Zdrój, Szczawno-Zdrój, Szklarska Poręba i Świeradów-Zdrój). Analizowane ośrodki turystyczne cechują się dużym potencjałem gospodarczym, a ich gospodarka opiera się na małych i bardzo małych podmiotach gospodarczych z sektora usługowego. Specyfika lokalnych rynków pracy w przypadku ośrodków turystycznych wyraża się przez: stabilność rynku pracy w zakresie liczby pracujących, duże znaczenie funkcji egzogenicznych, przewagę liczby miejsc pracy nad liczbą miejsc zamieszkania i dobrze wykształcone strefy dojazdów do pracy, obejmujące zwykle kilka gmin sąsiadujących z danym miastem.
\end{abstract}

Słowa kluczowe: ośrodki turystyczne, lokalne rynki pracy, turystyka, małe miasta, Sudety

JEL: J21, J61, L83, Z32

\section{Wstęp}

Jedną z podstawowych funkcji turystyki jest funkcja ekonomiczna, która przyczynia się do rozwoju społeczno-gospodarczego krajów lub regionów recepcji turystycznej, a także pojedynczych jednostek osadniczych (por. Gaworecki 2003, Czerwiński 2007, Kurek 2007, Marak, Wyrzykowski 2010). Rozwój turystyki może przyczyniać się do przeobrażeń morfo-strukturalnych i funkcjonalnych, dzięki czemu dawne
Historia: otrzymano 2015-10-16, poprawiono 2015-12-15, zaakceptowano 2016-02-17

osiedla wiejskie stają się ośrodkami turystycznymi o funkcjach nierolniczych, które swym charakterem bardziej przypominają miasta niż wsie. W literaturze proces ten określany jest terminem "urbanizacji turystycznej” (Dziegieć 1995, Jakóbczyk-Gryszkiewicz 2012).

Miasta, z uwagi na znaczenie funkcji turystycznej, można podzielić na dwie grupy. Do pierwszej z nich należą te, w których turystyka nie jest funkcją dominującą (a tylko jedną z funkcji 
uzupełniających). Do drugiej grupy można zaliczyć ośrodki, w których turystyka stanowi podstawę funkcjonowania gospodarki miejskiej, a często - przyczyniła się do powstania miasta (będąc czynnikiem miastotwórczym). Miasta te określa się mianem ośrodków turystycznych. Cechują się wysokim stopniem zagospodarowania turystycznego, oferując zróżnicowane usługi turystyczne (Czerwiński 2007). Zazwyczaj są to miasta małe (w miastach dużych i średniej wielkości, z uwagi na ich złożony charakter funkcjonalny, turystyka bardzo rzadko stanowi dominującą funkcję gospodarczą) (por. Suliborski 2001, Sokołowski 2006, Szmytkie 2009), położone w głównych regionach turystycznych. Głównym celem artykułu jest ocena wpływu turystyki na gospodarkę małych miast, będących ośrodkami turystycznymi (czyli miast liczących do 20 000 mieszkańców, w których turystyka stanowi dominujący rodzaj działalno$\left.{ }^{s} \mathrm{ci}^{1}\right)$, rozpatrywanych $\mathrm{w}$ kontekście lokalnych rynków pracy (por. Gruchociak 2012). Analizę przeprowadzono na przykładzie małych miast województwa dolnośląskiego, które należy do regionów o najwyższym w kraju poziomie rozwoju turystyki (Turystyka... 2015). Z uwagi na uwarunkowania przyrodnicze ruch turystyczny na terenie Dolnego Śląska koncentruje się w południowej, sudeckiej części województwa. Na obszarze Sudetów zlokalizowane są najbardziej znane ośrodki turystyczne w regionie (Duszniki-Zdrój, Karpacz, Kudowa-Zdrój, Lądek-Zdrój, Polanica-Zdrój, Szczawno-Zdrój, Szklarska Poręba i Świeradów-Zdrój). W badaniach wykorzystano:

- dane na temat podmiotów gospodarczych i zagospodarowania turystycznego, pochodzące z Banku Danych Lokalnych GUS;

$\overline{1 \mathrm{~W}}$ opracowaniu pominięto miasta duże i średniej wielkości, w których turystyka niezwykle rzadko stanowi podstawę funkcjonowania gospodarki miejskiej.
- $\quad$ wyniki Badania Aktywności Ekonomicznej Ludności (BAEL) z 2011 r. na temat dojazdów do pracy ${ }^{2}$;

- niepublikowane dane na temat liczby pracujących w odniesieniu do sekcji PKD pozyskane w Urzędzie Statystycznym we Wrocławiu.

\section{Funkcje turystyczne małych miast Dolnego Śląska}

Funkcje turystyczne miasta zwykle rozpatrywane są przez pryzmat (por. Kowalczyk 2001, Kruczek 2002, Lijewski i in. 2002, Czerwiński 2007):

- wielkości bazy noclegowej, wyrażonej np. wskaźnikiem Baretje'a i Deferta, czyli liczbą miejsc noclegowych przypadających na 100 mieszkańców,

- $\quad$ znaczenia turystyki dla gospodarki miasta, wyrażonego liczbą podmiotów gospodarczych z branży turystycznej przypadających na 1000 mieszkańców ${ }^{3}$,

- natężenia ruchu turystycznego, wyrażonego np. liczbą osób korzystających z noclegów w obiektach noclegowych (lub liczbą osób odwiedzających atrakcje turystyczne) w stosunku do liczby mieszkańców miejscowości,

- atrakcyjności turystycznej miasta, wyrażonej w liczbie i znaczeniu atrakcji turystycznych zlokalizowanych na terenie miasta.

W 2012 r. najwyższą wartością wskaźnika rozwoju funkcji turystycznej Baretje'a i Deferta spośród małych miast województwa dolnośląskiego

\footnotetext{
$\overline{2}$ Dostępne na stronie internetowej GUS: www.stat.gov.pl.

3 Podmioty z branży turystycznej obejmują następujące działy wg klasyfikacji PKD: 55 (Zakwaterowanie), 56 (Działalność usługowa związana $\mathrm{z}$ wyżywieniem), 79 (Działalność organizatorów turystyki, pośredników i agentów turystycznych oraz pozostała działalność usługowa w zakresie rezerwacji i działalności z nią związane) i 93 (Działalność sportowa, rozrywkowa i rekreacyjna).
} 
cechowały się (ryc. 1): Karpacz (190,8 miejsc noclegowych na 100 mieszkańców), Szklarska Poręba $(65,2)$, Świeradów-Zdrój $\quad(56,3), \quad$ Radków $(36,0)$, Duszniki-Zdrój $(32,4)$, Kudowa-Zdrój $(25,8)$, Polanica-Zdrój $(25,0)$, Szczawno-Zdrój $(16,8)$ i Lądek-Zdrój $(13,6)$. Z wyjątkiem Radkowa miasta te znajdują się też $w$ czołówce zestawienia dotyczącego liczby podmiotów gospodarczych z branży turystycznej w przeliczeniu na 1000 mieszkańców. Najwyższym znaczeniem turystyki dla gospodarki w przypadku małych miast Dolnego Śląska wyróżniały się bowiem (ryc. 2): Karpacz $(76,1)$, Szklarska Poręba $(52,1)$, Świeradów-Zdrój $(29,1)$, Polanica-Zdrój (22,4), Lądek-Zdrój $(16,3)$, Duszniki-Zdrój $(15,7)$, Kudowa-Zdrój $(14,3)$ i Szczawno-Zdrój $(13,6)$. Miasta te można zatem uznać jako najważniejsze ośrodki turystyczne na terenie województwa dolnośląskiego.

W zakresie uwarunkowań rozwoju turystyki wymienione miasta są podobne do siebie. Wszystkie są ośrodkami wypoczynkowymi o długich tradycjach turystycznych, położonymi w sudeckiej części województwa. Sześć z nich (Duszniki, Kudowa, Lądek, Polanica,

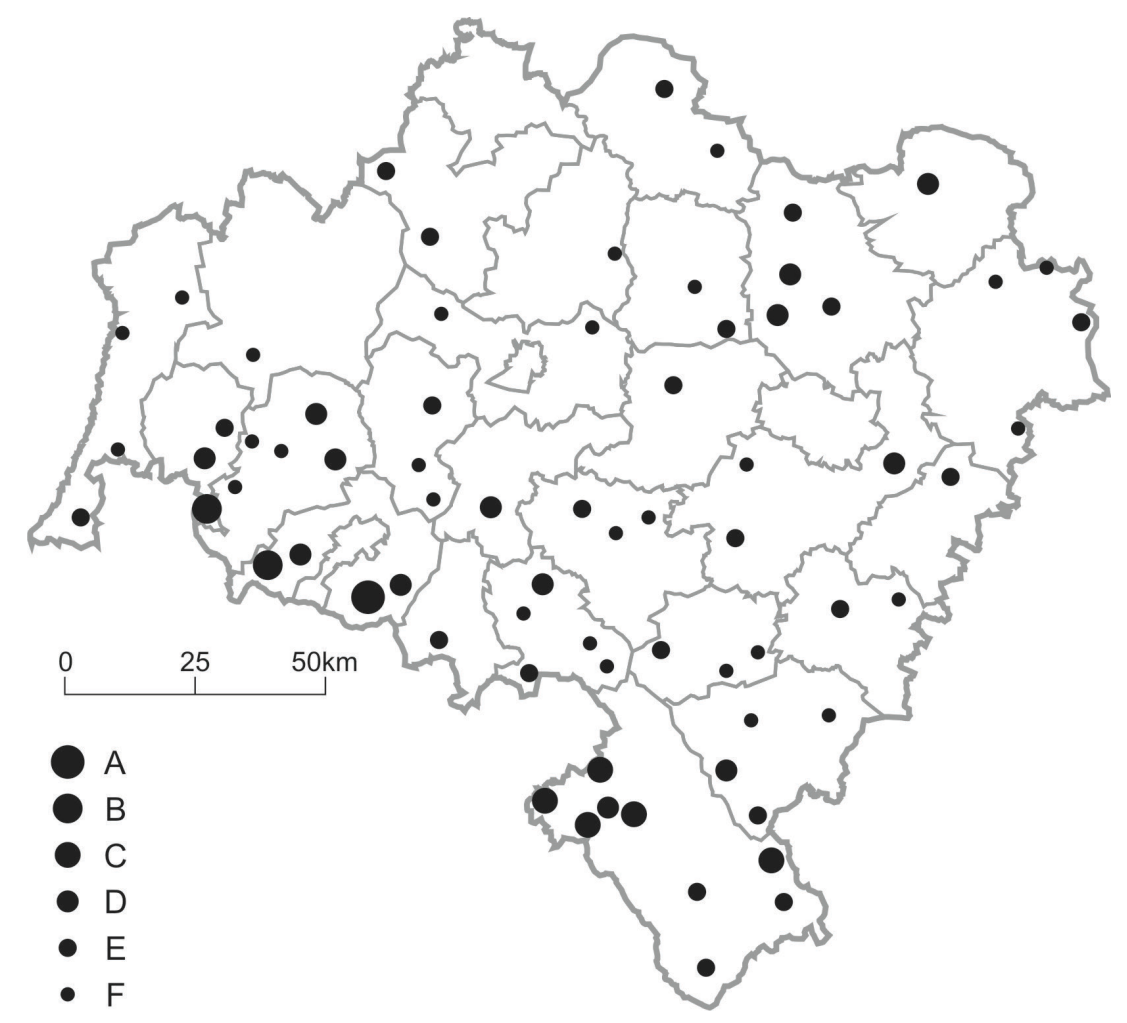

Ryc. 1. Wskaźnik rozwoju funkcji turystycznej Baretje’a i Deferta w małych miastach województwa dolnośląskiego w 2012 r.

Liczba miejsc noclegowych na 100 mieszkańców: A) ponad 75,0; B)

$50,1-75,0$; C) $10,1-50,0$; D) 3,1-10,0; E) 0,1-3,0; F) 0,0

Źródło: opracowanie własne na podstawie Banku Danych Lokalnych GUS 


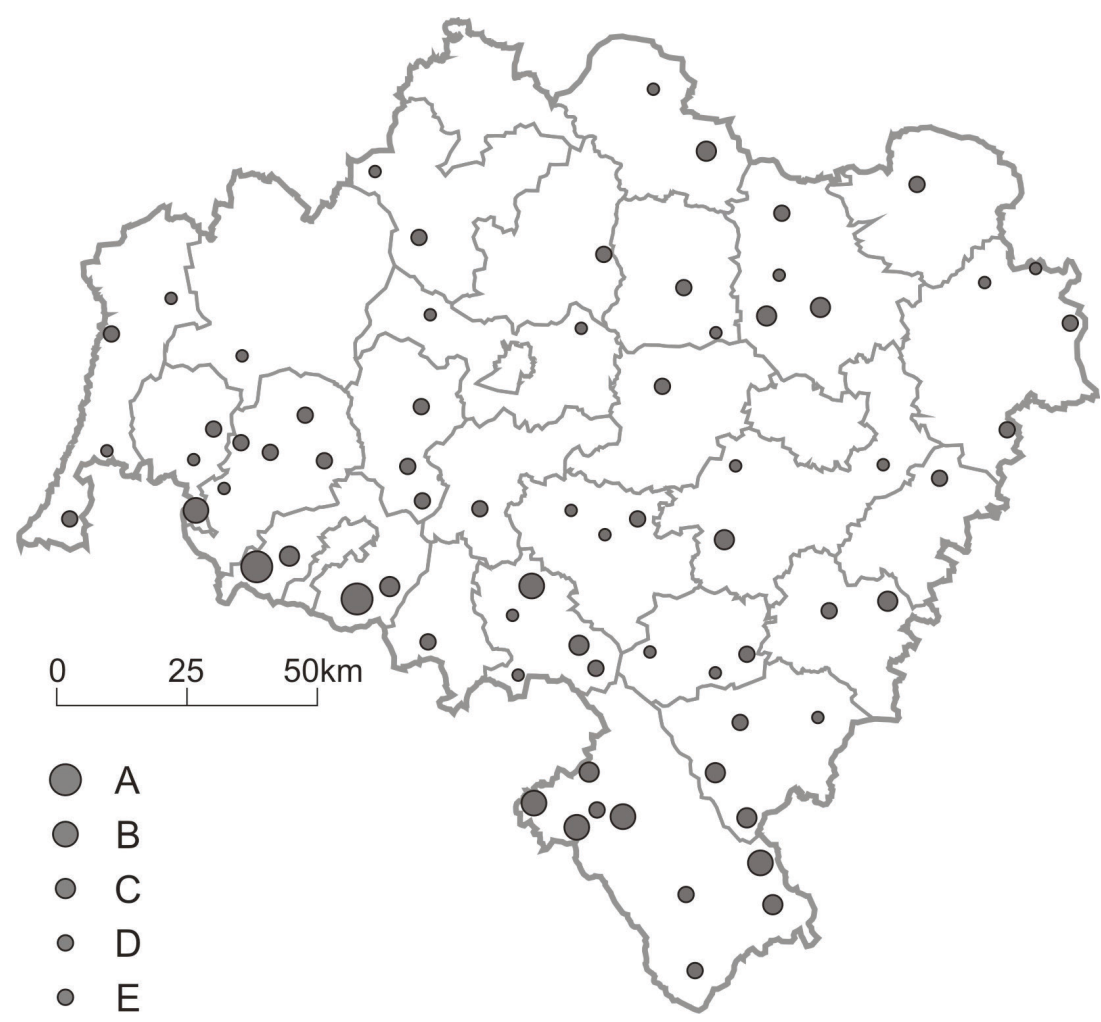

Ryc. 2. Podmioty z branży turystycznej na 1000 mieszkańców w małych miastach województwa dolnośląskiego w 2012 r.

Podmioty z branży turystycznej na 1000 mieszkańców: A) powyżej 30,0 ; B) 10,0-29,9; C) 6,0-9,9; D) 4,0-5,9; E) 2,0-3,9

Źródło: opracowanie własne na podstawie Banku Danych Lokalnych GUS

Szczawno i Świeradów) posiada status uzdrowiska, opierając się na lokalnych źródłach wód mineralnych, a Karpacz i Szklarska Poręba są stacjami klimatycznymi, wykorzystującymi w lecznictwie chorób górnych dróg oddechowych walory klimatyczne (Czerwiński 2009). Duszniki-Zdrój, Karpacz, Szklarska Poręba i Świeradów-Zdrój są ponadto znaczącymi ośrodkami sportów zimowych. Jeśli chodzi o przynależność do regionów turystycznych (Lijewski i in. 2002), to Karpacz, Szklarska Poręba i Świeradów-Zdrój położone są w Sudetach Jeleniogórskich, Szczawno-Zdrój w Sudetach Wałbrzyskich, natomiast Duszniki-Zdrój, Kudowa-Zdrój, Lądek-Zdrój i Polanica-Zdrój w Sudetach Kłodzkich (Ziemia Kłodzka).

We wszystkich omawianych przykładach rozwój funkcji turystycznej przyczynił się do dominacji sektora usługowego w strukturze funkcjonalnej miasta (Szmytkie 2009 i 2015). Udział pracujących w usługach waha się od 82,4\% w Kudowie-Zdroju do $95,0 \%$ w Karpaczu (tab. 1). W nawiązaniu do typologii funkcjonalnej 
Tab. 1. Struktura pracujących i typy funkcjonalne ośrodków turystycznych w Sudetach w 2013 r.

\begin{tabular}{|c|c|c|c|c|c|}
\hline \multirow{2}{*}{ Miasto } & \multicolumn{3}{|c|}{ Udział pracujących [\%] } & \multicolumn{2}{c|}{ Typ funkcjonalny } \\
\cline { 2 - 6 } & rolnictwo & przemysł & usługi & wg Jerczyńskiego & wg Szmytkie \\
\hline Duszniki-Zdrój & 4,1 & 9,8 & 86,1 & $U$ & $8 \mathrm{U} 1 \mathrm{P}$ \\
\hline Karpacz & 2,0 & 3,0 & 95,0 & $\mathrm{U}$ & $9 \mathrm{U}$ \\
\hline Kudowa-Zdrój & 2,1 & 15,5 & 82,4 & $\mathrm{U}$ & $8 \mathrm{U} 1 \mathrm{P}$ \\
\hline Lądek-Zdrój & 1,4 & 9,1 & 89,5 & $\mathrm{U}$ & $9 \mathrm{U}$ \\
\hline Polanica-Zdrój & 2,2 & 14,4 & 83,4 & $\mathrm{U}$ & $8 \mathrm{U} 1 \mathrm{P}$ \\
\hline Szczawno-Zdrój & 0,4 & 4,8 & 94,8 & $\mathrm{U}$ & $9 \mathrm{U}$ \\
\hline Szklarska Poręba & 2,4 & 7,0 & 90,6 & $\mathrm{U}$ & $9 \mathrm{U}$ \\
\hline Świeradów-Zdrój & 4,4 & 6,1 & 89,5 & $\mathrm{U}$ & $9 \mathrm{U}$ \\
\hline
\end{tabular}

Typy funkcjonalne miast: $\mathrm{U}$ - usługowy; $9 \mathrm{U}$ - miasta typowo usługowe, 8U1P - miasta zdominowane przez usługi ze śladowym udziałem przemysłu.

Źródło: opracowanie własne. Dane na temat liczby pracujących pozyskano w Urzędzie Statystycznym we Wrocławiu. Struktura pracujących wg M. Jerczyńskiego (1977) i R. Szmytkie (2015)

zaproponowanej M. Jerczyńskiego (1977) wszystkie analizowane miasta mieszczą się w obrębie typu usługowego (U), natomiast $w$ nawiązaniu do metody określania proporcji zatrudnienia i wyznaczania elementów wiodących w strukturze funkcjonalnej, która stanowi modyfikację metody kolejnych ilorazów (Szmytkie 2015) miasta te mieszczą się w obrębie dwóch typów funkcjonalnych:

- 8U1P - miasta zdominowane przez usługi (ok. $78-87 \%$ pracujących) ze śladowym udziałem przemysłu (ok. 10-20\% pracujących),

- $9 \mathrm{U}$ - czyli miasta typowo usługowe z zatrudnieniem w usługach powyżej $88 \%$.

\section{Baza ekonomiczna ośrodków turystycznych w Sudetach}

Analizowane ośrodki turystyczne cechują się wysokim potencjałem gospodarczym, wyrażonymliczbą podmiotów gospodarczych na 1000 mieszkańców, a także znaczną liczbą pracujących w stosunku do liczby ludności (tab. 2). O potencjale gospodarczym ośrodków turystycznych świadczy fakt, że Karpacz, Szczawno-Zdrój i Szklarska Poręba charakteryzują się największą spośród miast województwa dolnośląskiego liczbą podmiotów gospodarczych na 1000 mieszkańców (Szmytkie 2015). W sumie w 8 analizowanych miastach pracuje blisko 17,5 tys. zatrudnionych (ok. 1,7\% ogółu pracujących w województwie). W nawiązaniu do specyfiki rynku pracy, miasta te można podzielić na trzy grupy:

- miasta o wysokim natężeniu podmiotów gospodarczych i liczby pracujących (Karpacz, Polanica-Zdrój i Szczawno-Zdrój),

- miasta o wysokim natężeniu podmiotów gospodarczych i średnim natężeniu liczby pracujących (Duszniki-Zdrój, Szklarska Poręba, Świeradów-Zdrój),

- miasta o średnim natężeniu podmiotów gospodarczych i liczby pracujących (Lądek-Zdrój i Kudowa-Zdrój).

Można zatem stwierdzić, że analizowane miasta (ośrodki turystyczne) stanowią silne i wewnętrznie zróżnicowane rynki pracy (wszystkie miasta cechują 
Tab. 2. Podmioty gospodarcze i pracujący w ośrodkach turystycznych w Sudetach w 2013 r.

\begin{tabular}{|c|c|c|c|c|c|}
\hline \multirow{2}{*}{ Miasto } & \multicolumn{2}{|c|}{ Podmioty gospodarcze } & \multicolumn{3}{c|}{ Pracujący } \\
\cline { 2 - 6 } & ogółem & $\begin{array}{c}\text { na 1000 } \\
\text { mieszk. }\end{array}$ & ogółem & $\begin{array}{c}\text { na 100 } \\
\text { mieszk. }\end{array}$ & $\begin{array}{c}\text { w podmiotach } \\
\text { do 9 pracujących }\end{array}$ \\
\hline Duszniki-Zdrój & 634 & 129,4 & 1424 & 29,1 & $40,2 \%$ \\
\hline Karpacz & 1260 & 253,6 & 2460 & 49,5 & $53,3 \%$ \\
\hline Kudowa-Zdrój & 1050 & 102,5 & 2646 & 25,8 & $35,8 \%$ \\
\hline Lądek-Zdrój & 683 & 115,4 & 1608 & 27,2 & $37,6 \%$ \\
\hline Polanica-Zdrój & 1085 & 162,8 & 2601 & 39,0 & $37,7 \%$ \\
\hline Szczawno-Zdrój & 1137 & 196,2 & 2792 & 48,2 & $36,7 \%$ \\
\hline Szklarska Poręba & 1321 & 192,5 & 2411 & 35,1 & $48,6 \%$ \\
\hline Świeradów-Zdrój & 588 & 135,4 & 1546 & 35,6 & $34,5 \%$ \\
\hline
\end{tabular}

Źródło: opracowanie własne. Dane na temat liczby pracujących pozyskano w Urzędzie Statystycznym we Wrocławiu

się bowiem bardzo dużym zróżnicowaniem rodzajów działalności). Ich gospodarka w dużym stopniu opiera się jednak na bardzo małych podmiotach usługowych (czyli mikroprzedsiębiorstwach, zatrudniających do 9 pracujących). Dobrze widoczne jest to zwłaszcza w przypadku Karpacza i Szklarskiej Poręby (tab. 2), a w mniejszym stopniu również w przypadku miast posiadających status uzdrowiska (udział pracujących w mikroprzedsiębiorstwach jest w nich zaniżony przez duże podmioty związane z funkcją uzdrowiskową).

Ośrodki turystyczne w Sudetach wykazują jednak znaczne zróżnicowanie w zakresie bazy ekonomicznej, rozpatrywanej $\mathrm{w}$ kontekście relacji dojazdów do pracy (tab. 3). Spośród analizowanych miast najwięcej osób dojeżdża do pracy w Polanicy-Zdroju, Szczawnie-Zdroju i Karpaczu. W większości ośrodków turystycznych dojeżdżający do pracy stanowią ponad $20 \%$ ogółu pracujących w mieście, co wskazuje na duże znaczenie funkcji egzogenicznych, które tworzą podstawę gospodarczą (bazę ekonomiczną) miasta. Wyjątek stanowią Duszniki-Zdrój,
Szklarska Poręba i Kudowa-Zdrój, gdzie udział dojeżdżających do pracy jest zdecydowanie niższy, co może wynikać m.in. z peryferyjnego położenia (Kudowa-Zdrój) lub konkurencji z innymi ośrodkami turystycznymi (Szklarska Poręba, Duszniki-Zdrój).

Duszniki-Zdrój, Kudowa-Zdrój i Szczawno-Zdrój to jedyne spośród analizowanych miast, w których liczba wyjeżdżających do pracy przewyższa liczbę dojeżdżających do pracy. W Dusznikach-Zdroju i Kudowie-Zdroju wynika to z ogólnie małej liczby dojeżdżających do pracy, natomiast w przypadku Szczawna-Zdroju z dużej rotacji pracujących, co wyraża się w znacznej liczbie osób dojeżdżających i wyjeżdżających do pracy. Ta wyjątkowa intensywność dojazdów do pracy wynika z silnych powiązań funkcjonalno-przestrzennych między miastami wchodzącymi w skład aglomeracji wałbrzyskiej (Szmytkie 2015). W pozostałych ośrodkach turystycznych liczba dojeżdżających przewyższa liczbę wyjeżdżających do pracy.

Analizując funkcje ośrodków turystycznych w Sudetach w kontekście 
Tab. 3. Struktura dojazdów do pracy w ośrodkach turystycznych w Sudetach w 2011 r.

\begin{tabular}{|c|c|c|c|c|c|}
\hline \multirow[b]{2}{*}{ Miasto } & \multicolumn{3}{|c|}{ Liczba osób } & \multirow{2}{*}{$\begin{array}{l}\text { Stosunek } \\
\text { liczby } \\
\text { miejsc pracy } \\
\text { do liczby } \\
\text { miejsc za- } \\
\text { mieszkania }\end{array}$} & \multirow{2}{*}{$\begin{array}{c}\text { Udział } \\
\text { dojeżdżają- } \\
\text { cych w licz- } \\
\text { bie pracu- } \\
\text { jących }\end{array}$} \\
\hline & pracujących & $\begin{array}{l}\text { dojeżdża- } \\
\text { jących do } \\
\text { pracy }\end{array}$ & $\begin{array}{l}\text { wyjeżdża- } \\
\text { jących do } \\
\text { pracy }\end{array}$ & & \\
\hline Duszniki-Zdrój & 1424 & 181 & 184 & 99,8 & $12,7 \%$ \\
\hline Karpacz & 2460 & 581 & 236 & 116,3 & $23,6 \%$ \\
\hline Kudowa-Zdrój & 2646 & 148 & 201 & 98,0 & $5,6 \%$ \\
\hline Lądek-Zdrój & 1608 & 324 & 259 & 104,2 & $20,1 \%$ \\
\hline Polanica-Zdrój & 2601 & 768 & 212 & 127,2 & $29,5 \%$ \\
\hline Szczawno-Zdrój & 2792 & 624 & 681 & 98,0 & $22,3 \%$ \\
\hline Szklarska Poręba & 2411 & 312 & 261 & 102,2 & $12,9 \%$ \\
\hline Świeradów-Zdrój & 1546 & 316 & 86 & 117,5 & $20,4 \%$ \\
\hline
\end{tabular}

Źródło: opracowanie własne. Dane na temat dojazdów do pracy z BAEL GUS

relacji między liczbą miejsc pracy a liczbą miejsc zamieszkania, można je podzielić na dwie grupy (por. Dziewoński 1971, Maik 1992, Suliborski 2001, Sokołowski 2006) (tab. 3):

- miasta o silnej funkcji miejsca pracy (Karpacz, Polanica-Zdrój, Świeradów-Zdrój);

- miasta o zrównoważonym układzie miejsc pracy i miejsc zamieszkania (Duszniki-Zdrój, Kudowa-Zdrój, Lądek-Zdrój, Szczawno-Zdrój, Szklarska Poręba).

\section{Strefy dojazdów do pracy w ośrodkach turystycznych w Sudetach}

O znaczeniu miast turystycznych w Sudetach jako lokalnych rynków pracy świadczą strefy dojazdów do pracy, które można utożsamiać jako strefy oddziaływania poszczególnych ośrodków. W przypadku analizowanych miast obejmują one kilka gmin (5-10), przy czym strefa intensywnych dojazdów do pracy zwykle obejmuje dwie lub trzy gminy sąsiadujące $z$ danym ośrodkiem. Analiza zasięgów oddziaływania poszczególnych ośrodków turystycznych w nawiązaniu do głównych regionów turystycznych wykazuje następujące prawidłowości:

- w regionie jeleniogórskim główne ośrodki turystyczne, z uwagi na ich przestrzenną izolację, posiadają wyraźnie określone strefy oddziaływania (ryc. 3):

a) w przypadku Karpacza obejmuje miasta Jelenia Góra i Kowary oraz gminy wiejskie Podgórzyn i Mysłakowice,

b) w przypadku Szklarskiej Poręby - miasta Jelenia Góra i Piechowice,

c) w przypadku Świeradowa-Zdroju - miasto Mirsk oraz obszary wiejskie w gminach Mirsk i Leśna;

- w regionie kłodzkim, z uwagi na liniowe ułożenie miast wzdłuż ciągu komunikacyjnego z Kłodzka do Kudowy-Zdroju, dochodzi do nakładania się stref oddziaływania głównych ośrodków turystycznych (ryc. 4), tworzących zespół tzw. uzdrowisk kłodzkich (Duszniki-Zdrój, Kudowa-Zdrój, 


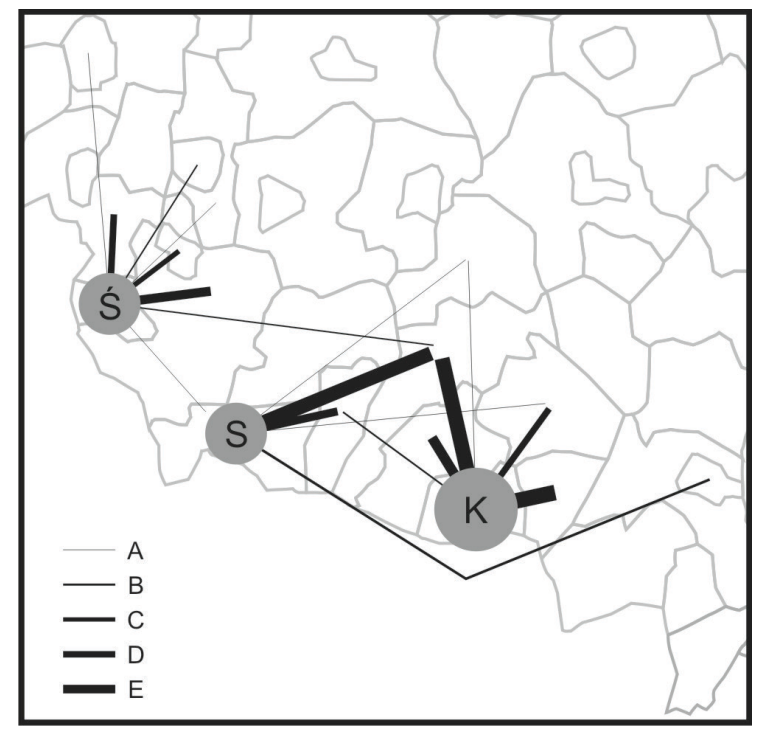

Ryc. 3. Strefy dojazdów do pracy w głównych ośrodkach turystycznych regionu jeleniogórskiego Objaśnienia: K - Karpacz, S - Szklarska Poręba, Ś - Świeradów-Zdrój Liczba dojeżdżających do pracy: A - 10 osób, B - 25 osób, C - 50 osób, D-75 osób, E- 100 osób Źródło: opracowanie własne. Dane na temat dojazdów do pracy z BAEL GUS

Polanica-Zdrój). Dobrze widoczne jest to zwłaszcza w przypadku gminy miejsko-wiejskiej Szczytna, która stanowi zaplecze mieszkaniowe dla wszystkich trzech miast. Zdecydowanie największą strefę oddziaływania posiada Polanica-Zdrój (12 gmin), która obok Kłodzka stanowi główny rynek pracy w całym powiecie kłodzkim (por. Szmytkie 2015). Wyraźnie odrębną od miast tworzących zespół tzw. uzdrowisk kłodzkich strefę oddziaływania posiada z kolei Lądek-Zdrój. Obejmuje ona południowo-wschodnią część powiatu kłodzkiego (czyli obszar dawnego powiatu bystrzyckiego), a zwłaszcza gminę miejsko-wiejską Stronie Śląskie i wiejską część gminy Lądek-Zdrój;

- Szczawno-Zdrój, stanowiące najważniejszy ośrodek turystyczny w regionie wałbrzyskim, wykazuje bardzo silne, dwukierunkowe powiązania w zakresie dojazdów do pracy jedynie z Wałbrzychem (ryc. 5), co wynika głównie z przestrzennej integracji obu miast i dużej liczby połączeń komunikacyjnych między nimi (Szczawno-Zdrój jest bowiem obsługiwane przez komunikację miejską Wałbrzycha). Strefa dojazdów do pracy obejmuje również inne gminy sąsiadujące ze Szczawnem (Boguszów-Gorce, Świebodzice i Stare Bogaczowice).

\section{Podsumowanie i wnioski}

Przeprowadzone analizy potwierdzają znaczenie turystyki w kształtowaniu gospodarki miast - ośrodków turystycznych. Miasta te cechują się dużym potencjałem gospodarczym, wyrażonym w liczbie podmiotów gospodarczych i liczbie pracujących w stosunku 


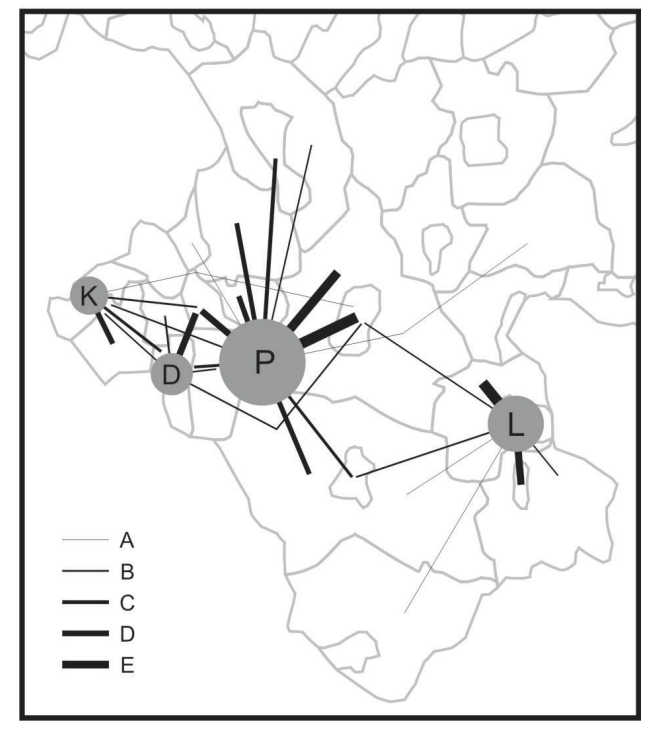

Ryc. 4. Strefy dojazdów do pracy w głównych ośrodkach turystycznych regionu kłodzkiego

Objaśnienia: D - Duszniki-Zdrój, K - Kudowa-Zdrój, L - Lądek-Zdrój, P - Polanica-Zdrój Liczba dojeżdżających do pracy: A - 10 osób, B - 25 osób, C - 50 osób, D - 75 osób, E- 100 osób Źródło: opracowanie własne. Dane na temat dojazdów do pracy z BAEL GUS

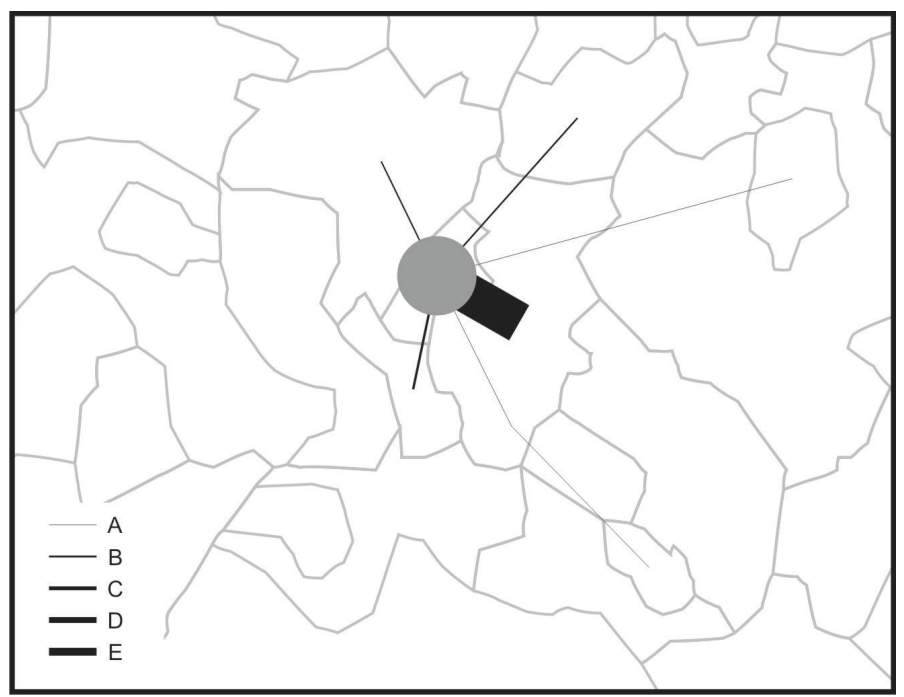

Ryc. 5. Strefy dojazdów do pracy w głównych ośrodkach turystycznych regionu wałbrzyskiego Liczba dojeżdżających do pracy: A - 10 osób, B - 25 osób, C - 50 osób, D - 75 osób, E - 100 osób Źródło: opracowanie własne. Dane na temat dojazdów do pracy z BAEL GUS 
sezonowo zwiększona przez wielkość ruchu turystycznego liczba użytkowników miasta). Specyfika lokalnych rynków pracy w przypadku ośrodków turystycznych wyraża się ponadto przez:

- stabilność rynku pracy w zakresie liczby pracujących (Szmytkie 2008),

- duże znaczenie funkcji egzogenicznych (co wyraża się dużym udziałem dojeżdżających do pracy w stosunku do liczby pracujących),

- $\quad$ przewagę liczby miejsc pracy nad liczbą miejsc zamieszkania,

- dobrze wykształcone strefy dojazdów do pracy (tzn. strefy bezpośredniego oddziaływania), obejmujące zwykle kilka gmin sąsiadujących z danym miastem.

Na obszarze Sudetów, z uwagi na intensywność ruchu turystycznego

\section{Bibliografia}

Czerwiński J. (2007), Podstawy turysty$k i$, Legnica, Wydawnictwo PWSZ.

Czerwiński J. (2009), Dolny Ślq̨sk. Przewodnik, Wrocław, Wydawnictwo Kartograficzne EKO-GRAF.

Dziegieć E. (1995), Urbanizacja turystyczna terenów wiejskich w Polsce, „Turyzm" 5(1), s. 5-51.

Dziewoński K. (1971), Baza ekonomiczna i struktura funkcjonalna miast. Studium rozwoju pojęć, metod $i$ ich zastosowań, Warszawa, „Prace Geograficzne IG PAN" 63, s. 9-110.

Gaworecki W. (2003), Turystyka, Warszawa, Polskie Wydawnictwo Ekonomiczne.

Gruchociak H. (2012), Delimitacja lokalnych rynków pracy w Polsce, „Przegląd Statystyczny”, nr spec. 2, s. 277-297. i koncentrację atrakcji turystycznych, ma miejsce także znacząca konkurencja między głównymi ośrodkami turystycznymi w poszczególnych regionach. Dobrze widoczne jest to zwłaszcza w regionie jeleniogórskim, gdzie do trwającej już od kilkudziesięciu lat konkurencji między Karpaczem a Szklarską Porębą o miano turystycznej stolicy Karkonoszy dołączył Świeradów-Zdrój, który w ostatnich latach postawił na rozwój turystyki jako ośrodek sportów zimowych. Podobna sytuacja ma również miejsce w przypadku uzdrowisk kłodzkich, co zaowocowało niezwykle intensywnym rozwojem zagospodarowania turystycznego oraz tworzeniem nowych atrakcji turystycznych w poszczególnych ośrodkach (Miszewska, Szmytkie 2012).

Jakóbczyk-Gryszkiewicz J. (2012), Procesy urbanizacji [w:] Geografia urbanistyczna, red. S. Liszewski, Warszawa, Wydawnictwo Naukowe PWN, s. 175-206.

Jerczyński M. (1977), Funkcje i typy funkcjonalne polskich miast. Zagadnienia dominacji funkcjonalnej [w:] Statystyczna charakterystyka miast. Funkcje dominujqce, „Statystyka Polski" 85, Warszawa, GUS, s. 20-53.

Kowalczyk A. (2001), Geografia turyzmu, Warszawa, PWN.

Kruczek Z. (2002), Polska. Geografia atrakcji turystycznych, Kraków, Proksenia.

Kurek W. (2007), Turystyka, Warszawa, Wydawnictwo Naukowe PWN.

Lijewski T., Mikułowski B., Wyrzykowski J. (2002), Geografia turystyki Polski, Warszawa, PWE. 
Maik W. (1992), Podstawy geografii miast, Toruń, Wydawnictwo UMK.

Marak J., Wyrzykowski J. (red.) (2010), Turystyka w ujęciu interdyscyplinarnym, Wrocław, Wydawnictwo Wyższej Szkoły Handlowej.

Miszewska B., Szmytkie R. (2012), Próba zmiany wizerunku małych miast Dolnego Slquska pod wpływem nowych atrakcji turystycznych [w:] Ewolucja funkcji małych miast w Polsce, Studia Ekonomiczne, red. K. Heffner, A. Halama, „Zeszyty Naukowe Uniwersytetu Ekonomicznego w Katowicach" 92, s. 110-123.

Sokołowski D. (2006), Funkcje centralne i hierarchia funkcjonalna miast w Polsce, Toruń, Uniwersytet Mikołaja Kopernika.

Suliborski A. (2001), Funkcje i struktura funkcjonalna miast. Studia empiryczno-teoretyczne, Łódź, Wydawnictwo Uniwersytetu Łódzkiego.
Szmytkie R. (2008), Zmiany liczby zatrudnionych $w$ miastach województw dolnoślqskiego i opolskiego w latach 1998-2005 [w:] Mechanizmy i uwarunkowania budowania konkurencyjności miast, red. J. Słodczyk, E. Szafranek, Uniwersytet Opolski, s. 247-254.

Szmytkie R. (2009), Zróżnicowanie funkcjonalne małych miast województwa dolnoślqaskiego [w:] Struktura funkcjonalna małych miast, red. T. Marszał, Wydawnictwo Uniwersytetu Łódzkiego, s. 7-24.

Szmytkie R. (2015), Demograficzne i gospodarcze aspekty rozwoju miast Dolnego Ślqska, Wrocław, Instytut Rozwoju Terytorialnego we Wrocławiu, dostępne na: www.irt.wroc.pl.

Turystyka w Polsce w 2014 r. (2015), „Informacje i opracowania statystyczne", Warszawa, GUS.

\title{
Tourist Centres in the Sudetes as Local Labour Markets
}

\begin{abstract}
The main subject of this paper is to analyse the influence of tourism on local economies of small towns functioning as tourist centres. The analysis was carried out on the example of 8 small towns in Lower Silesia (Duszniki Zdrój, Karpacz, Kudowa Zdrój, Lądek Zdrój, Polanica Zdrój, Szczawno Zdrój, Szklarska Poręba and Świeradów Zdrój). The mentioned tourist centres have great economic potential, but their economies are based on large amount of small and very small business entities from the service branch. The specificity of local labour markets in the case of tourist centres can be described by stability of the labour market in the range of the number of workers, marked significance of exogenous functions, advantage of the number of job places over the number of dwelling places, and the existence of the local zones of intensive commuting to work, comprising few communes neighbouring the given town.
\end{abstract}

Keywords: tourist centres, local labour markets, tourism, small towns, the Sudetes 
